\title{
Isolation and Characterisation of Sulphur Oxidizing Bacteria Isolated from Hot Spring in Malaysia for Biological Deodorisation of Hydrogen Sulphide in Chicken Manure
}

\author{
M. Y. Hidayat ${ }^{a}$, H. M. Saud ${ }^{\mathrm{b}}$, \& A. A. Samsudin ${ }^{\mathrm{a}, *}$ \\ aDepartment of Animal Science, Faculty of Agriculture, Universiti Putra Malaysia \\ bepartment of Agriculture Technology, Faculty of Agriculture, Universiti Putra Malaysia \\ 43400 Serdang, Selangor, Malaysia \\ (Received 27-10-2017; Reviewed 17-11-2017; Accepted 30-11-2017)
}

\begin{abstract}
In this study, the isolation of sulphur oxidising bacteria (SOB) from hot spring in Malaysia was carried out in an enrichment culture using sodium thiosulphate as a sole energy and $\mathrm{CO}_{2}$ as a sole carbon source. A total number of $80 \mathrm{SOB}$ isolates were obtained from the agar plate and considered as positive SOB due to their abilities using thiosulphate for growth. All the isolates were initially screened for their fast growths in liquid medium and 13 isolates were selected for another screening process. Three SOB isolates namely isolate $\mathrm{AH} 18, \mathrm{AH} 25$, and $\mathrm{AH} 28$ were selected based on their abilities to grow faster, produce the highest sulphate ion and reducing the $\mathrm{pH}$ in the growth medium. The cells were Gram-negative and short rod-shaped. The effects of various variables including temperature $\left(25-45^{\circ} \mathrm{C}\right), \mathrm{pH}(4-9)$, sodium thiosulphate concentrations (4-100 $\mathrm{mM}$ ) and metabolic characteristic were evaluated on bacterial growth and their sulphur oxidation activities. The optimum $\mathrm{pH}$ of all the potential isolates occurred at $\mathrm{pH}$ 8.0. Meanwhile, the optimum temperature for isolate AH18, AH25 and AH28 occurred at $45{ }^{\circ} \mathrm{C}, 30^{\circ} \mathrm{C}$, and 30$45{ }^{\circ} \mathrm{C}$, respectively. The three isolates were classified as facultative chemolithotroph with the capability of growth in thiosulphate concentration as high as $100 \mathrm{mM}$. Therefore, given the ability in the oxidation of thiosulphate, temperature and $\mathrm{pH}$ adaptabilities, with the metabolic flexibilities of isolates AH18, AH25, and AH28 could be a good $\mathrm{H}_{2} \mathrm{~S}$ biological deodorizing candidate.
\end{abstract}

Keywords: sulphur oxidising bacteria, hot spring, biological deodorisation, chicken manure, hydrogen sulphide

\section{ABSTRAK}

Dalam kajian ini, proses isolasi bakteri pengoksidasi sulfur (SOB) dari sumber mata air panas di Malaysia dilakukan dalam media kultur dengan menggunakan natrium tiosulfat sebagai satu-satunya sumber energi dan $\mathrm{CO}_{2}$ sebagai sumber karbon tunggal. Sebanyak 80 isolat SOB diperoleh dari media agar dan dianggap sebagai SOB positif karena kemampuannya menggunakan tiosulfat untuk pertumbuhan. Semua isolat pada awalnya ditapis berdasarkan pada pertumbuhan yang cepat dalam media pertumbuhan cair dan 13 isolat telah terpilih untuk proses penapisan berikutnya. Tiga isolat SOB, yaitu isolat AH18, AH25, dan AH28 dipilih berdasarkan kemampuan pertumbuhan yang cepat, menghasilkan ion sulfat tertinggi, dan menurunkan $\mathrm{pH}$ dalam medium pertumbuhan. Berdasarkan pengamatan mikroskopis, semua sel bakteri yang diuji merupakan bakteri Gram-negatif dan berbentuk batang pendek. Berbagai peubah diuji termasuk variasi berbagai suhu $\left(25-45^{\circ} \mathrm{C}\right), \mathrm{pH}(4-9)$, konsentrasi natrium tiosulfat (4-100 mM), dan karakteristik metabolik diamati pada kemampuan pertumbuhan bakteri dan aktivitas oksidasinya. Nilai $\mathrm{pH}$ optimum bagi semua isolat pontensial adalah 8.0. Sementara itu, suhu optimum untuk isolat AH18, AH25, dan AH28 masing-masing adalah $45{ }^{\circ} \mathrm{C}$, $30{ }^{\circ} \mathrm{C}$, dan $30-45^{\circ} \mathrm{C}$. Ketiga isolat tersebut diklasifikasikan sebagai chemolithotroph fakultatif dengan kemampuan pertumbuhan pada konsentrasi tiosulfat setinggi $100 \mathrm{mM}$. Oleh karena itu, berdasarkan kemampuan bakteri mengoksidasi tiosulfat, pertumbuhan pada berbagai suhu dan $\mathrm{pH}$, dengan fleksibilitas metabolik isolat AH18, AH25 dan $\mathrm{AH} 28$ bisa menjadi penghilang bau $\mathrm{H}_{2} \mathrm{~S}$ secara biologis yang efisien.

Kata kunci: bakteri pengoksidasi sulfur, mata air panas, penghilang bau $\mathrm{H}_{2} \mathrm{~S}$ secara biologis, ekskreta, hidrogen sulfida

*Corresponding author:

E-mail: anjas@upm.edu.my 


\section{INTRODUCTION}

Poultry farm emits a large number of odorous gases such as ammonia, carbon monoxide, carbon dioxide, methane, hydrogen sulphide, dimethylamine, mercaptans, and phenolic compounds (Gutarowska et al., 2014) which derived from the manure. However, among all of the manure gases, hydrogen sulphide $\left(\mathrm{H}_{2} \mathrm{~S}\right)$ is known as the most toxic and dangerous gas. It can be identified by its characteristic smell of rotten eggs which causing community problems by creating an unpleasant condition of working and living environment. In addition, $\mathrm{H}_{2} \mathrm{~S}$ is generated in lower abundance but significantly contributes to the total odorous nuisance due to their very low odour threshold limits (Kim et al., 2007). This situation has created never-ending conflicts between the poultry farm and the surrounding residential area. Therefore, removal or reduction of $\mathrm{H}_{2} \mathrm{~S}$, especially in the chicken manure, is necessary.

The removal of $\mathrm{H}_{2} \mathrm{~S}$ can be done through physicochemical methods including by the effective use of oxidising biocides such as chlorine $\left(\mathrm{Cl}_{2}\right)$, hydrogen peroxide $\left(\mathrm{H}_{2} \mathrm{O}_{2}\right)$, and sodium hypochlorite $(\mathrm{NaClO})$ (Oprime et al., 2001). However, the processes based on such agents are expensive due to the high cost involved in the facility installation, as well as the operational cost and the use of toxic chemical may have a greater tendency to generate secondary pollution (Dehghanzadeh et al., 2011). On the other hand, the biological method by using microorganisms has drawn much attention due to its cost-effectiveness with higher removal efficiency and environmentally friendly (De Gusseme et al., 2009; Lin et al., 2013). Biological treatment works on the principle which microorganisms such as bacteria act as a catalyst for the conversion of volatile pollutants into a less harmful form.

Sulphur oxidising bacteria (SOB) play a key role in the removal process of $\mathrm{H}_{2} \mathrm{~S}$ and other reduced inorganic sulphur compounds (thiosulphate, sulphite, and elemental sulphur) due to the fact that these compounds can serve as an energy source and/or a carbon sources for bacterial metabolism and thus, the harmful gasses can be eliminated. SOB is physiologically diverse, which can be characterised by a wide variety genera, broad habitat diversity, and can be classified by their metabolic characteristics including heterotrophic, mixotrophic, chemolithotrophic (colourless bacteria), and photoautotrophic (green and purple bacteria) (Ehrlich \& Newman, 2009). There is a variety of SOB that have been employed to remove $\mathrm{H}_{2} \mathrm{~S}$ biologically and the most widely study SOB reported belongs to Thiobacillus spp. including Thiobacillus thioparus (Chung et al., 2007) which classified as a chemolithotrophic SOB. On the other hand, chemoorganotrophic SOB such as Pseudomonas spp. and Xanthomonas spp. have also been reported to be capable of oxidising $\mathrm{H}_{2} \mathrm{~S}$ (Xu et al., 2016; Ho et al., 2008; \& Chung et al., 1996).

Sulphur oxidising bacteria can be found in a variety of environments including soil, water, and geothermal area. They can be found in the environment where the sulphur compounds are in higher concentrations which can provide good habitats for SOB (Druschel et al.,
2003). Hot spring is believed to have a high amount of saturated sulphur and various reduced sulphur compounds in the water due to the mud or the sediment are composed of sulphur compounds, which can potentially act as electron donors for SOB growth (Watsuntorn et al., 2017). Additionally, microorganisms that live in hot spring water have minimal requirements for nutrients and their metabolic activities only depend on the biogeochemical cycle such as sulphur and other mineral contents (Skirnisdottir et al., 2000). It is therefore of importance to isolate and select a potential SOB that can oxidize reduced inorganic sulphur compounds including $\mathrm{H}_{2} \mathrm{~S}$, sulphide, sulphur, thiosulphate, and grow well at variable temperatures and $\mathrm{pH}$. To our knowledge, the study on isolation of SOB inhabit hot spring water in order to reduce the $\mathrm{H}_{2} \mathrm{~S}$ in poultry manure is not available publicly. Thus, the objective of this study is to isolate and characterize the potential SOB from hot spring water in Malaysia and to evaluate its potential application in biological deodorisation of $\mathrm{H}_{2} \mathrm{~S}$ in poultry manure.

\section{MATERIALS AND METHODS}

\section{Sample Collection}

The hot spring water was collected from three different hot springs located in Malaysia which is Poring hot spring Sabah $\left(6^{\circ} 02^{\prime} 44.9^{\prime \prime} \mathrm{N} 116^{\circ} 42^{\prime} 13.5^{\prime \prime} \mathrm{E}\right)$, Selayang hot spring $\left(3^{\circ} 15^{\prime} 32.2^{\prime \prime} \mathrm{N} 101^{\circ} 38^{\prime} 47.6^{\prime \prime} \mathrm{E}\right)$, and Sungai Serai hot spring Selangor $\left(3^{\circ} 05^{\prime} 28.0^{\prime \prime} \mathrm{N} 101^{\circ} 47^{\prime} 42.0^{\prime \prime} \mathrm{E}\right)$. The samples sources were collected in $1 \mathrm{~L}$ sterile Schott bottle at a depth of $0.5 \mathrm{~m}$ from the water surface and transported to the research laboratory. The temperature and $\mathrm{pH}$ of the hot spring water were measured in situ. The samples were stored at $4{ }^{\circ} \mathrm{C}$ until further analysis.

\section{Medium and Culture Conditions}

The thiosulphate mineral medium (TSM) composition is as followed $(\mathrm{g} / \mathrm{L}): 1.5 \mathrm{~g} \mathrm{~K}_{2} \mathrm{HPO}_{4^{\prime}} 1.5 \mathrm{~g} \mathrm{KH}_{2} \mathrm{PO}_{4^{\prime}} 0.4$ $\mathrm{g} \mathrm{NH}_{4} \mathrm{Cl}, 0.8 \mathrm{~g} \mathrm{MgCl}_{2} .6 \mathrm{H}_{2} \mathrm{O}, 0.1 \mathrm{~g} \mathrm{CaCl}_{2} .2 \mathrm{H}_{2} \mathrm{O}$, and 10 $\mathrm{g} \mathrm{Na} \mathrm{S}_{2} \mathrm{O}_{3} \cdot 5 \mathrm{H}_{2} \mathrm{O}$. The $\mathrm{pH}$ of the medium was adjusted with $1 \mathrm{M} \mathrm{NaOH}$ or $\mathrm{HCl}$ to 7.5 and solid media was prepared by addition of $15 \mathrm{~g} / \mathrm{L}(1.5 \%)$ agar to the medium. The medium was sterilized in an autoclave at $121{ }^{\circ} \mathrm{C}$ for 20 min prior to its use.

\section{Quantification of Sulphate Ion}

The concentration of sulphate ion which was produced during the growth of SOB was determined by the method of Cha et al. (1999). Barium chloride $\left(\mathrm{BaCl}_{2}\right)$ solution $(10 \% \mathrm{w} / \mathrm{v})$ was added to culture supernatant in 1:1 and mixed up vigorously until a white turbid solution of barium sulphate $\left(\mathrm{BaSO}_{4}\right)$ was produced. Afterwards, the $\mathrm{BaSO}_{4}$ solution was measured at 480 $\mathrm{nm}$ by a spectrophotometer. The values obtained were compared with the sulphate standard curve (Kolmert et al., 2000). The standard sulphate solution was made by dissolving potassium sulphate $\left(\mathrm{K}_{2} \mathrm{SO}_{4}\right)$ in deionized water to a known concentration from 0 to $3 \mathrm{mM}$ and then was added with a $\mathrm{BaCl}_{2}$ solution which formed a white 
turbidity as the chemical reaction. The sulphate ion concentration is directly proportional to the turbidity of the solution.

\section{Enrichment and Isolation of Sulphur Oxidising Bacteria}

The enrichment was performed by placing $1 \mathrm{~mL}$ of liquid sample in a $250 \mathrm{~mL}$ Erlenmeyer flask containing $50 \mathrm{~mL}$ of sterilized TSM media with an initial $40 \mathrm{mM}$ concentration of thiosulphate and incubated at room temperature $\left(28 \pm 2^{\circ} \mathrm{C}\right)$ with $160 \mathrm{rpm}$ of agitation speed for $14 \mathrm{~d}$ until the medium turned turbid. After the incubation period, about $0.1 \mathrm{~mL}$ of the cultures were diluted in series $\left(10^{-2}\right.$ to $\left.10^{-4}\right)$ and then spread evenly onto TSM agar medium plate. The inoculated agar plate was incubated at room temperature $\left(28 \pm 2^{\circ} \mathrm{C}\right)$ for $72 \mathrm{~h}$ until the bacterial colonies were observed. The well-defined colonies were picked and re-streaked in fresh TSM agar to obtain pure cultures. A total number of 80 colonies were selected based on different colonial morphologies. The pure isolates obtained were labelled according to their sampling area and ecologies. The pure isolates were then sub-cultured by transfering of a single colony to fresh TSM growth medium broth and incubated at room temperature $\left(28 \pm 2^{\circ} \mathrm{C}\right)$ with $160 \mathrm{rpm}$ of agitation speed for $14 \mathrm{~d}$. Among these cultures, 13 isolates were selected based on their abilities to grow faster in the growth medium.

\section{Screening of Potential Sulphur Oxidising Bacteria}

The screening process was carried out using TSM broth with the addition of $0.01 \mathrm{~g}$ of bromocresol purple as the colour indicator of the $\mathrm{pH}$ changes. About $10 \%$ $(\mathrm{v} / \mathrm{v})$ of bacterial inoculum was inoculated and incubated at room temperature $\left(28 \pm 2{ }^{\circ} \mathrm{C}\right)$ aerobically with 160 rpm agitation speed for $14 \mathrm{~d}$. The procedure was carried out in triplicates and the potential SOB isolates were screened on the basis of their efficiencies in thiosulphate oxidation by producing the highest sulphate ion concentration and lowering $\mathrm{pH}$ in the growth medium (Ullah et al., 2013).

\section{Phenotypic Characterisation}

Cell morphology of the isolate AH18 was observed under a light microscope (NOVEX B-range) at 1000x magnification with oil immersion. Gram staining was performed by the Hucker method. The presence of catalase activity was determined by the formation of bubbles with $3 \%(\mathrm{v} / \mathrm{v})$ hydrogen peroxide solution and oxidase activity was determined with an oxidase test strip $\left(\mathrm{Oxoid}^{\mathrm{TM}}\right)$. The biochemical characteristics of the isolates on organic carbon substrate utilization were determined by using an API20E kit (BioMérieuxs, Marcy I'Etoile, France) and carried out according to the manufacturer's instructions.

\section{Effects of Physicochemical Properties on Microbial Growth and Sulphate Production of the Potential SOB Isolate}

TSM medium containing thiosulphate $(40 \mathrm{mM})$ as the electron donor under oxic conditions was used to determine the bacterial growth and sulphate ion production of the following changes to growth conditions:

1. $\mathrm{pH}$ of $4.0,5.0,6.0,7.0,8.0$, and 9.0. The cultures were incubated at room temperature $\left(28 \pm 2^{\circ} \mathrm{C}\right)$ with 160 rpm agitation speed for $7 \mathrm{~d}$.

2. Temperatures of $25,30,35$, and $45^{\circ} \mathrm{C}$. The cultures medium were set at $\mathrm{pH} 8.0$ and incubated with 160 rpm agitation speed for $7 \mathrm{~d}$.

3. Various thiosulphate concentrations were tested. 5 $\mathrm{mM}$ and $10 \mathrm{mM}$ was set as minimum concentration (Olguin-Lora et al., 2011), $40 \mathrm{mM}$ as initial concentration and $100 \mathrm{mM}$ as a maximum concentration (Makzum et al., 2016). The cultures media were set at $\mathrm{pH} 8.0$ (optimum $\mathrm{pH}$ ) and incubated at a temperature of $30{ }^{\circ} \mathrm{C}$ (optimum temperature) with 160 rpm agitation speed for $7 \mathrm{~d}$.

For bacterial growth, $1 \mathrm{~mL}$ samples were withdrawn every $24 \mathrm{~h}$ and optical density was measured by spectrophotometer at $660 \mathrm{~nm}$. The specific growth rate during logarithmic growth was determined for each temperature, $\mathrm{pH}$, and various thiosulphate concentration. For final sulphate ion concentration, about $2 \mathrm{~mL}$ samples were withdrawn after $7 \mathrm{~d}$ of incubation and the concentration of sulphate ion was determined by using $\mathrm{BaCl}_{2}$ as described by Cha et al. (1999) using spectrophotometer at $480 \mathrm{~nm}$. The procedure was carried out in triplicates.

\section{Metabolic Characterisation of the Potential SOB Isolate}

The ability of the potential SOB isolates to grow chemolithotrophically on different reduced inorganic sulphur compounds was tested in the TSM medium supplemented with one of the following compounds; sodium sulphide $(5 \mathrm{mM})$, tetrathionate $(10 \mathrm{mM})$, thiocyanate $(5 \mathrm{mM})$, and elemental sulphur $(0.1 \% \mathrm{w} / \mathrm{v})$. Chemoorganotroph growth was determined by using the TSM medium in which the sodium thiosulphate was replaced with the following organic compounds added at a concentration of $0.1 \%(\mathrm{w} / \mathrm{v})$ for organic nitrogen and $0.2 \%(\mathrm{w} / \mathrm{v})$ for carbohydrates (Vlasceanu et al., 1997) and incubated at $30^{\circ} \mathrm{C}$ aerobically for $3 \mathrm{~d}$. The following organic compounds tested were yeast extract, peptone, glucose, and sucrose. Meanwhile, for the mixotrophic growth test was determined in the TSM medium which was amended with $0.05 \%(\mathrm{w} / \mathrm{v})$ of yeast extract (Chen et. al., 2004) and incubated at $30^{\circ} \mathrm{C}$ (optimum temperature) aerobically for $7 \mathrm{~d}$.

For the mixotrophic growth, about $1 \mathrm{~mL}$ of broth was periodically sampled every $24 \mathrm{~h}$ to measure the optical density of cell growth with a spectrophotometer at $660 \mathrm{~nm}$. The specific growth rate of the isolate was determined and sulphate ion production was measured by using $\mathrm{BaCl}_{2}$ as described by Cha et al. (1999). Moreover, inoculated TSM medium without yeast extract was used 
as a control for the cell growth and sulphate ion production comparison. For chemolithotrophic growth, the sulphate ion production was measured and turbidity was observed and compared with control (without SOB). Meanwhile, for the chemoorganotrophic growth, the turbidity of broth was compared to the control (without $\mathrm{SOB})$. The procedures were carried out in triplicates for all the isolates in growth condition tested.

\section{Statistical Analysis}

All data were analysed using one-way ANOVA of Statistical Analysis System Package (SAS) Version 9.4 software. Duncan's Multiple Range Test was performed to determine differences in the mean of treatments. $P$ value was set at 0.05 .

\section{RESULTS}

\section{Isolation and Screening of the Potential SOB Isolate}

The approach of the current study was to isolate and screen a potential SOB from hot spring water in Malaysia. The samples were collected from three different hot springs in Malaysia, the $\mathrm{pH}$ and temperature were measured in situ $\left(45-55^{\circ} \mathrm{C}, \mathrm{pH} 7.5-7.8\right)$. After the enrichment and purification processes, a total number of 80 isolates were obtained and the colonies were choosing based on the size, colour, and shape. At this point, the colonies obtained from the isolation were considered as a positive SOB due to their abilities using thiosulphate for growth. The 80 isolates were subjected to undergo a screening process in order to choose the potential SOB and thirteen isolates were found to have the capability to grow faster based on the development of turbidity observed. The thirteen isolates were undergone another screening process and based on the results obtained (Figure 1), three isolates were found to show a significant sulphate ion concentration $(\mathrm{P}<0.05)$ and reducing the $\mathrm{pH}$ of the medium (based on colour changes). Moreover, the three potential SOB has recorded a final $\mathrm{pH}$ in the range of 5.8-6.0 from the initial $\mathrm{pH} 7.5$ in the broth using a $\mathrm{pH}$ meter. The three selected potential SOB was coded as isolate AH18, AH25, and AH28.

\section{Phenotypic and Biochemical Characteristics of the Potential SOB Isolate}

A single colony was observed appeared in less than $72 \mathrm{~h}$ incubation at room temperature $\left(28 \pm 2{ }^{\circ} \mathrm{C}\right)$ on TSM agar. Isolate AH25 and AH28 had formed a regular white colony, smooth and creamy morphology whereas for isolate AH18 had formed white, a wrinkled colony with a star shape. Light microscopy examination of all isolates showed that cells were Gram-negative with short rods shape and the cell exhibited positive results for catalase and oxidase. By using API 20E, isolate AH25 and AH28 exhibited a similar biochemical characteristics behaviour, in which Arginine DiHydrolyse, Lysine DeCarboxylase, Ornithine DeCarboxylase, Urease, Citrate utilisation and Voges Proskauer were found to be positive whereas ONPG, Tryptophane DeAminase, Gelatinase, $\mathrm{H}_{2} \mathrm{~S}$ production, indole production and all the fermentation of carbohydrates were found to be negative. On the other hand, isolate AH18 exhibited different biochemical behaviours whereas the entire test was found to be negative except for Tryptophane Deaminase and fermentation of D-glucose and D-melibiose which showed positive results. Their phenotypic and biochemical characteristics are summarized in Table 1.

\section{Effects of pH on Microbial Growth and Sulphur Oxidation Activity}

To determine the effect of $\mathrm{pH}$ on $\mathrm{SOB}$ growth rate and sulphur oxidation activity, TSM medium was pre-

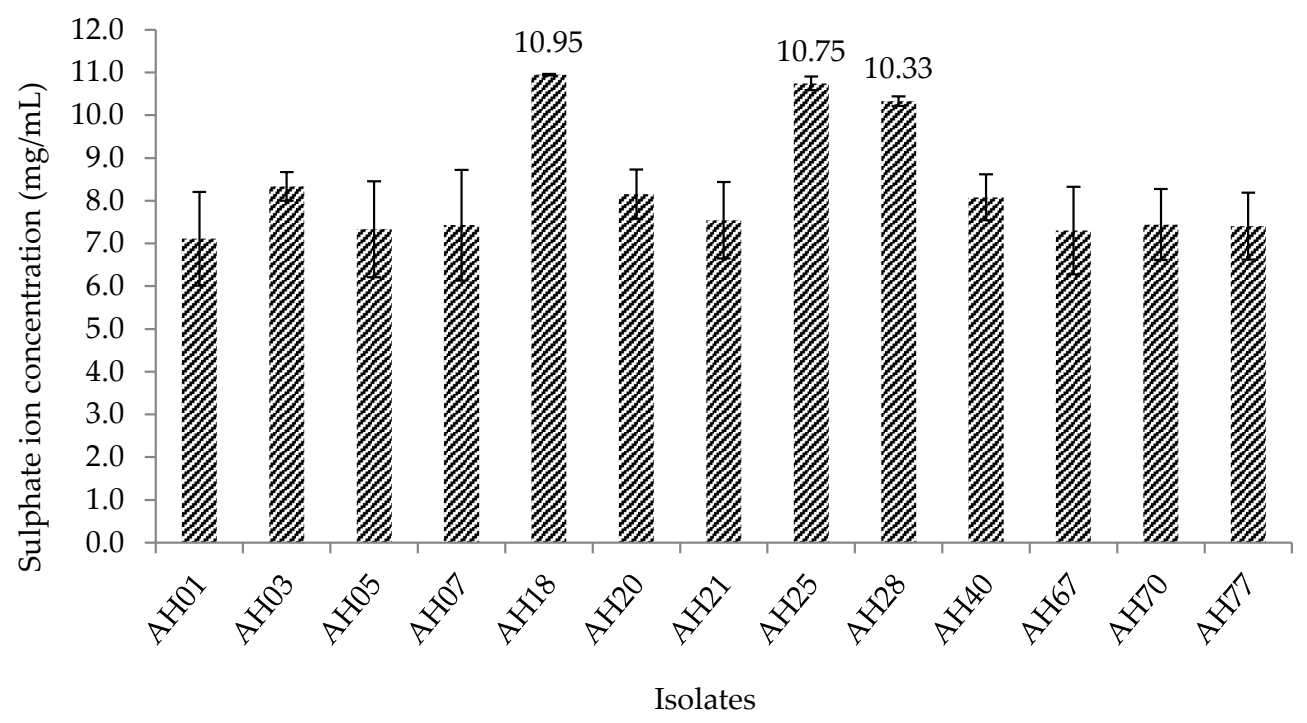

Figure 1. Screening results of sulphur-oxidising bacteria for sulphate ion production in TSM medium. Each point represents the mean of triplicate $\pm S E$ 
pared with six different $\mathrm{pH}(4.0,5.0,6.0,7.0,8.0$, and 9.0). As shown in Figure 2, the three potential SOB isolates were preferred to grow in the range of $\mathrm{pH} 6.0$ to 9.0 accompanied by the production of sulphate ion in the growth medium. Based on the results, it was observed

Table 1. Phenotypic and biochemical characteristics of the potential SOB isolates

\begin{tabular}{lccc}
\hline TRAITS & AH18 & AH25 & AH28 \\
\hline Phenotypic characteristic & $\begin{array}{c}\text { Gram- } \\
\text { negative }\end{array}$ & $\begin{array}{c}\text { Gram- } \\
\text { negative }\end{array}$ & $\begin{array}{c}\text { Gram- } \\
\text { negative }\end{array}$ \\
Cell type & Motile & Motile & Motile \\
Motility & Rod & Rod & Rod \\
Shape & + & + & + \\
Oxidase & + & + & + \\
Catalase & & & \\
\hline
\end{tabular}

\begin{tabular}{|c|c|c|c|}
\hline \multicolumn{4}{|l|}{ API20E kit } \\
\hline \multicolumn{4}{|l|}{ Enzymatic reactions } \\
\hline ONPG & - & - & - \\
\hline Arginine Dehydrolase & - & + & + \\
\hline Lysine Decarboxylase & - & + & + \\
\hline Ornithine Decarboxylase & - & + & + \\
\hline Urease & - & + & + \\
\hline Tryptophane Deaminase & + & - & - \\
\hline Gelatinase & - & - & - \\
\hline Citrate Utilisation & - & + & + \\
\hline H2S Production & - & - & - \\
\hline Indole Production & - & - & - \\
\hline Voges Proskauer & - & + & + \\
\hline \multicolumn{4}{|c|}{ Fermentation of carbohydrates } \\
\hline Glucose & + & - & - \\
\hline Mannitol & - & - & - \\
\hline Inositol & - & - & - \\
\hline Sorbitol & - & - & - \\
\hline Rhamnose & - & - & - \\
\hline Saccharose & - & - & - \\
\hline Melibiose & + & - & - \\
\hline Amygdalin & - & - & - \\
\hline Arabinose & - & - & - \\
\hline
\end{tabular}

Note: (+) Indicate a positive test result, (-) Indicate a Negative test result

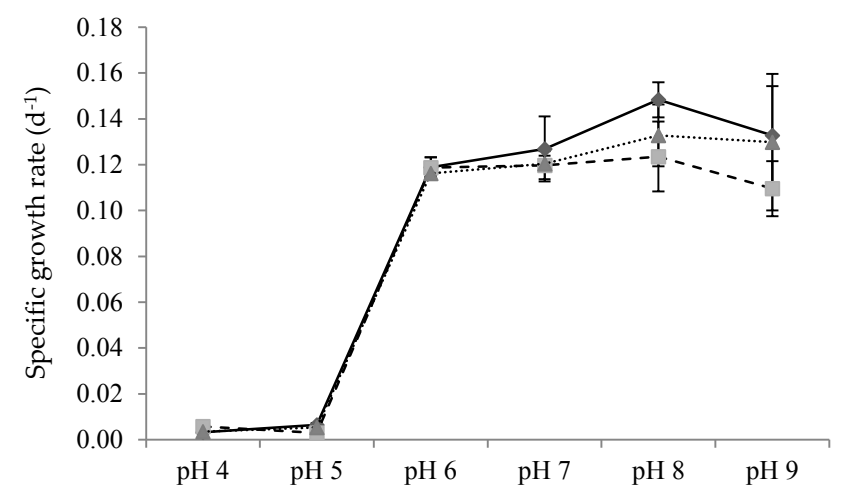

(a) that the optimal $\mathrm{pH}$ of growth and sulphur oxidation activity was 8.0. However, the three isolates showed no growth activity and sulphate ion production in the $\mathrm{pH}$ medium of 4.0 and $5.0(\mathrm{P}>0.05)$.

\section{Effects of Temperature on Microbial Growth and Sulphur Oxidation Activity}

The effects of temperature on the growth rate and sulphur oxidation activity of isolate AH18 are shown in Figure 3. The results showed that the three potential $\mathrm{SOB}$ isolates were able to grow over a broad range temperature investigated. Interestingly the microbial growth and sulphur oxidation activity of isolate AH18 and AH28 were observed increase with temperature increment and the optimal temperature was at $45^{\circ} \mathrm{C}(\mathrm{P}<0.05)$ and $30^{\circ} \mathrm{C}$ to $45^{\circ} \mathrm{C}(\mathrm{P}>0.05)$ respectively. Meanwhile, isolate $\mathrm{AH} 25$ shows a different bacteria growth and sulphur oxidation behaviour towards the temperature tested. The highest bacteria growth and sulphate ion production occurred at temperature $30^{\circ} \mathrm{C}$ $(\mathrm{P}<0.05)$ and was observed starts to decrease beyond that temperature.

\section{Effects of Various Thiosulphate Concentrations on Microbial Growth and Sulphur Oxidation Activity}

The concentration of thiosulphate tested in TSM was varied in a range of $5 \mathrm{mM}$ to $100 \mathrm{mM}$. As shown in Figure 4, the microbial growth rate of isolate AH18 and AH25 was significantly increased with the increment of thiosulphate concentrations tested. Moreover, the increased in cell growth was also observed accompanied by the increase in sulphate ion production in which sulphate ion concentration on medium containing $40 \mathrm{mM}$ and $100 \mathrm{mM}$ thiosulphate showed the highest $(\mathrm{P}<0.05)$ sulphate produced compared to medium $5 \mathrm{mM}$ and 10 $\mathrm{mM}$. Nevertheless, isolate AH28 show a similar pattern in terms of sulphate ion production in which sulphate ion concentration was increased with the increment of thiosulphate concentration $(\mathrm{P}<0.05)$. However, there is no significant difference in term of cell growth observed for isolate AH28 for all the temperatures tested.

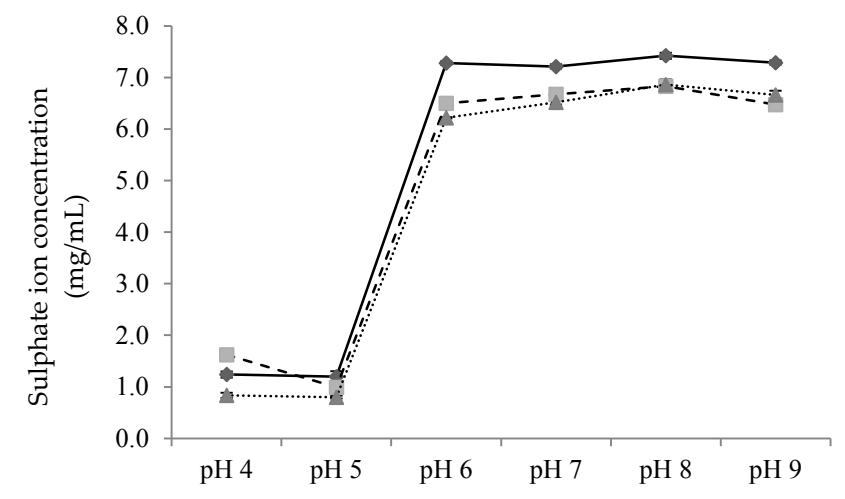

(b)

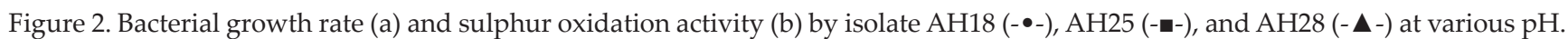
Each point represents the mean of triplicate \pm SE. 


\section{Metabolic Characteristics of the Potential SOB Isolate}

The chemolithotrophic growth of the isolate AH18, AH25 and AH28 occurred on growth medium supple-

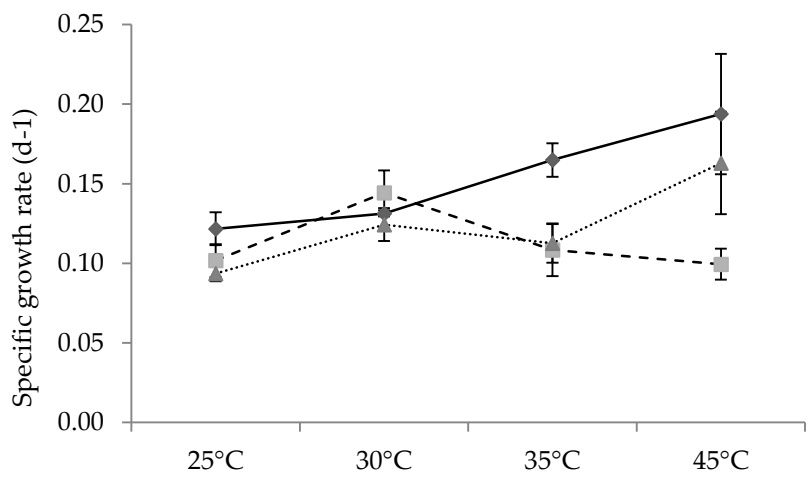

(a) mented with sulphide, tetrathionate, and elemental sulphur but not on thiocyanate. The ability of isolates to grow on the supplemented substrates was based on the turbidity observed and sulphate ion concentration mea-

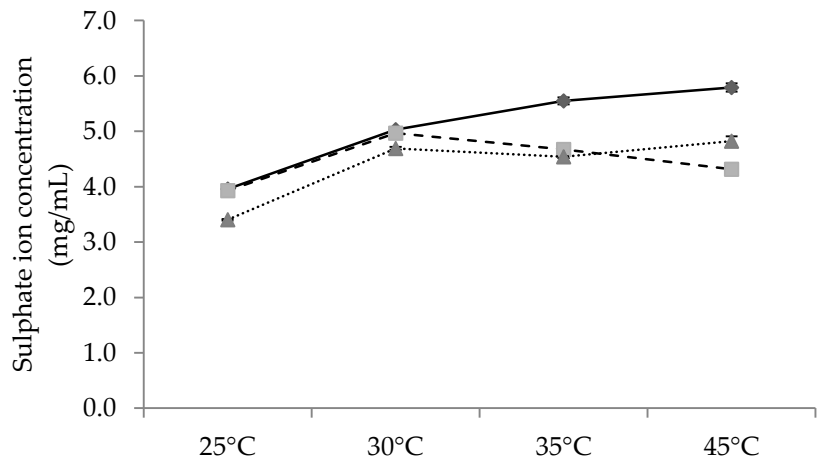

(b)

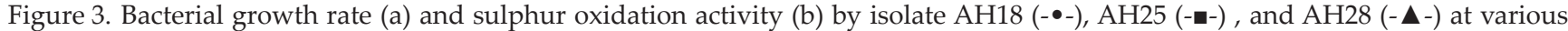
temperatures. Each point represents the mean of triplicate \pm SE.

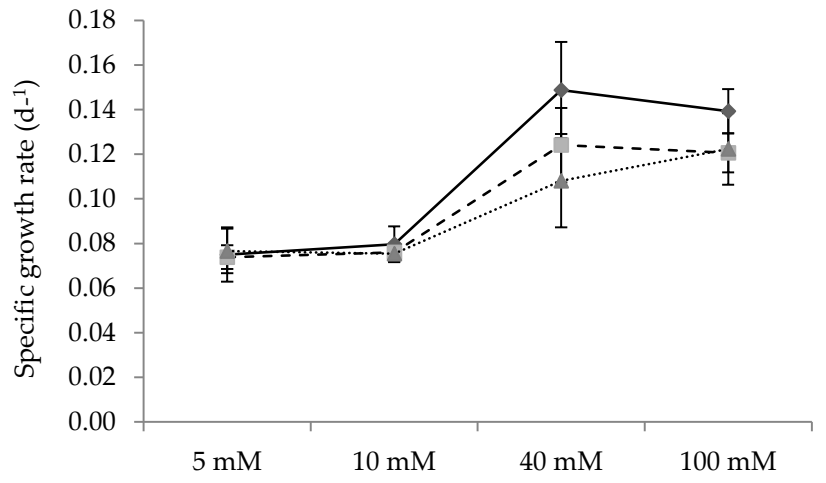

(a)

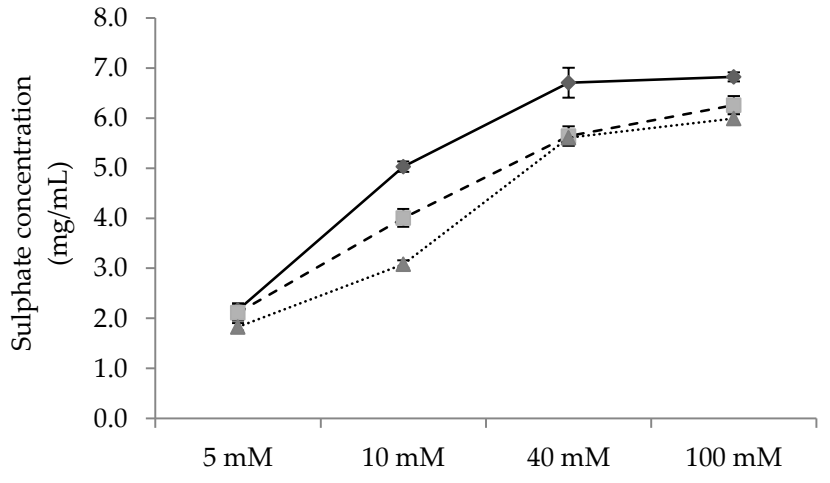

(b)

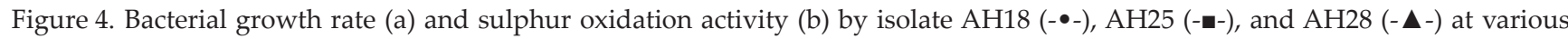
thiosulphate concentrations. Each point represents the mean of triplicate \pm SE.

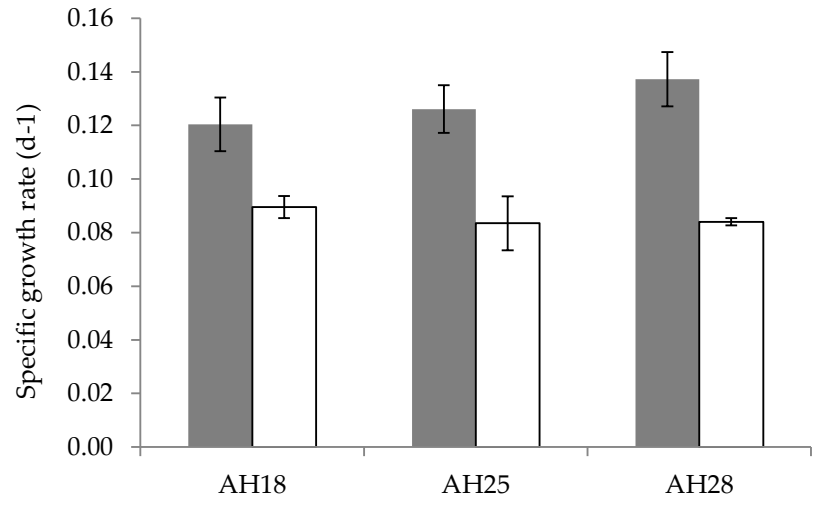

(a)

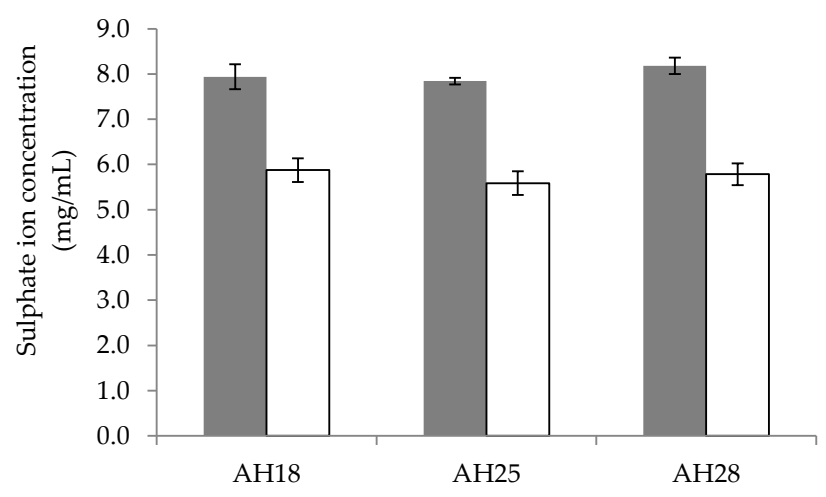

(b)

Figure 5. The specific growth rate (a) and sulphate ion production (b) of isolate AH18, AH25, and AH28 on TSM medium amended with $0.05 \%(\mathrm{w} / \mathrm{v})$ of yeast extract $(\mathbf{\square})$ and without yeast extract $(\square)$. Each point represents the mean of triplicate \pm SE. 
surement. Meanwhile, chemoorganotroph growth of isolate AH18 on medium supplemented with peptone, yeast extract, glucose, and sucrose without any reduced inorganic sulphur compound showed a positive growth. On the other hand, isolate AH25 and AH28 showed negative growths in medium supplemented with peptone, glucose and sucrose except in yeast extract. Furthermore, the observation was similar to the result obtained in carbohydrate substrate tested with API 20E which showed negative results for all carbohydrate substrate tested on isolates AH25 and AH28. Interestingly, all the isolates were observed to grow rapidly when the TSM medium was amended with yeast extract for mixotrophic growth. As shown in Figure 5, the microbial growth rate and the production of sulphate ion were significantly higher $(\mathrm{P}<0.05)$ in medium amended with yeast extract compared to the medium without yeast extract for all the isolates.

\section{DISCUSSION}

The present study dealt with the isolation, screening, and characterisation of SOB from hot spring water in Malaysia. Three out of 13 isolates were selected as potential sulphur oxidizer bacteria for their ability to oxidize thiosulphate efficiently and produce the highest sulphate ion. In this study, thiosulphate was used in the enrichment and isolation medium as a selective substrate without the addition of any particular carbon sources order to stimulate the consumption of thiosulphate by the bacteria as a sole energy source. Additionally, thiosulphate has been used as the substrate for isolation of SOB because it is more readily soluble in water and non-toxic at a high concentration (Kuenen et al. 1992). The potential SOB isolates were also able to reduce $\mathrm{pH}$ in the growth medium which was a consequent of sulphuric acid production resulting from the biological oxidation of thiosulphate that was also reported by Hassan et al. (2010) and Yang et al. (2010) in their studies. However, in this study, the formation of sulphuric acid has reached a level in which is not favourable for SOB and brings the growth to a halt state. Similar to the works of Watsuntorn et al. (2017), which have observed no bacteria growth at a $\mathrm{pH}$ below 7.0 of SOB strain MAL 1HM19 isolated from hot spring in Thailand. Moreover, Hydrogenobater sp. which was also isolated from hot spring by Skirnisdottir et al. (2001b) could only reduce the thiosulphate medium to $\mathrm{pH}$ 5-5.5 from the initial $\mathrm{pH}$ of 7.3. Similar to the study of Vidyalakshmi \& Sridar (2007) in isolation of Thiobacillus from various sources, 14 out of the 28 isolates were screened based on their efficacies to reduce the $\mathrm{pH}$ of growth medium from 8.0 to 5.0.

Most of the microorganisms prefer a specific $\mathrm{pH}$ range in which a change in $\mathrm{pH}$ can affect their growths and activities. Thus, it is important to investigate the optimal $\mathrm{pH}$ range of the microorganisms. In this study, the microbial growth and sulphur oxidation activity of all the potential SOB isolates were observed occurred under the neutral and slightly alkaline conditions with the optimum $\mathrm{pH}$ was 8.0. From the literature, the optimum $\mathrm{pH}$ for $\mathrm{SOB}$ was varied depending on the microbial habitat. The Thioalkalivibrio jannaschii isolated from hypersaline alkaline Mono Lake grow optimally at pH 10 (Sorokin et al., 2002), while Thiobacillus thiooxidans isolated from highly acidic Crater Lake is able to grow down to $\mathrm{pH}$ 2.0-3.5 (Takano et al., 1997). This result was strengthened by the fact that, hot spring water in Malaysia is known as the non-volcanic origin and most of the $\mathrm{pH}$ ranging between the values of 7.0 to 9.0 (Baioumy et al., 2015). Thus, the $\mathrm{pH}$ preference of the isolate in this study is not surprising since the enrichment condition used is in a neutral condition $(\mathrm{pH} 7.5)$ as well as the environment $\mathrm{pH}$ from which it is isolated. However, the growth of all the potential isolates was inhibited under acidic condition. This could be due to the deterioration of the microbial growth activity and the metabolism activity under the inappropriate $\mathrm{pH}$ conditions and thus indicated the neutrophilic character of all the potential isolates. Moreover, the inhibition of growth under acidic condition was also supported by the small $\mathrm{pH}$ reduction during the screening process. The optimum $\mathrm{pH}$ obtained in this study is within the range reported for other SOB (Vikromvarasiri et al., 2015; Park et al., 2011). In addition, several representatives of Thiobacillus sp. have shown neutrophilic character such as Thiobacillus novellus and Thiobacillus thioparus with optimal $\mathrm{pH}$ of 7.0 and 7.5, respectively (Pokorna \& Zabranska, 2015). Therefore, from the practical point of view, the ability of potential SOB to grow on varies $\mathrm{pH}$ conditions (except on acidic condition) would help the isolates to cope with the variable $\mathrm{pH}$ in biological deodorisation process since the $\mathrm{pH}$ of chicken manure is under neutral to alkaline condition.

The temperature requirements of some SOB are different and mostly they were found as mesophilic or thermophilic bacteria. In this study, all the potential SOB were capable of growing in the range of temperature tested $\left(25-45^{\circ} \mathrm{C}\right)$ with the different optimum temperatures recorded. However, the activity of isolate AH25 was observed decreasing with the increment of temperatures tested and the cell growth was observed slower at a temperature of $45^{\circ} \mathrm{C}$ compared to the other isolates. This is understandable that the SOB inhabits the hot spring has undergone a physiological adaptation during the storage time as well as during the enrichment process at room temperature and thus isolate AH25 was classified as a mesophilic SOB. This was in line with Watsuntorn et al. (2017) study, in which only recorded an optimal temperature at $35{ }^{\circ} \mathrm{C}$ in SOB of strain MAL 1HM19 which was isolated from hot spring with in situ temperature at $70{ }^{\circ} \mathrm{C}$. In fact, the ability of the potential SOB isolates to grow up to $45^{\circ} \mathrm{C}$ was due to the natural habitat of bacteria itself which is from the hot spring. Meanwhile, isolate AH18 and AH28 have recorded an optimal temperature up to $45^{\circ} \mathrm{C}$ and can be classified as moderate thermophilic bacteria which would be an advantage for these isolates for other use. Skirnisdottir et al. (2001a) isolated Thermus scotoductus from hot spring in Iceland which capable of growing and consuming thiosulphate at a high temperature of $65{ }^{\circ} \mathrm{C}$. Hence, well adapted to variables temperature could be advantages for the isolate for in situ biological deodorisations in the tropical region. 
Studies have shown that all the potential isolates were able to grow in thiosulphate concentration up to $100 \mathrm{mM}$ in which, the microbial growth of the isolates was influenced by the amount of thiosulphate concentration added in the growth medium. This observation was in line with the study of Spring et al. (2001) which observed the increase in cell growth was accompanied by the increment of thiosulphate concentration in the medium of Limnobacter thiooxidans. This result can be explained by the availability of the substrate (thiosulphate) which was enough to supply energy to the bacteria for growth and produced significant sulphate ion concentration. In contrast with Skirnisdottir et al., (2001b) works, which the increases in thiosulphate concentration has affected the conversion of thiosulphate to sulphate by Hydrogenobacter sp. and this could be explained due to the thiosulphate toxicity at high concentration which repressed the thiosulphate oxidation ability by the bacteria (Lee et al., 2000).

All the potential isolates were classified as a facultative chemolithotroph because exhibited both chemolithotroph and chemoorganotroph (heterotroph) growth. It can be seen by the turbidity observed and the presence of sulphate ion in the culture medium which indicated that the isolates were able to oxidise the supplemented reduced inorganic sulphur compounds as an energy source for growth. However, no bacterial growth was observed in the medium supplemented with thiocyanate as an energy source as the bacteria grew extremely poorly under this condition. Similarly, Shi et al. 2011 and Chen et al. 2004 also have reported that SOB isolates unable to grow on medium supplemented with thiocyanate as an energy source. This could be due to the lack of enzyme that is used as a catalyst to break down the thiocyanate molecule. From the literature, thiocyanate is a chemically stable compound and only a few chemolithotrophic SOB are capable of using thiocyanate as an electron donor for growth. In Bezsudnova et al. (2007) study, a novel halophilic SOB Thiohalophilus thiocyanoxidans was capable of growing with thiocyanate as an electron donor for growth and have recorded a high cyanase activity. Similar to Sorokin et al., (2014) which has proven the obligately chemolithoautotrophic Halothiobacillus strain was capable of using thiocyanate as an energy source for growth. Interestingly, all the isolates were observed prefer to chemoorganotroph grow in medium supplemented with yeast extract compared to other organic compounds. This can be validated by the results of biochemical characteristics (Table 1) in which the isolates AH25 and AH28 were unable to utilise all the carbohydrate substrates tested. Additionally, based on the biochemical test results, isolates AH25 and AH28 could be identical species because of exhibiting similar biochemical behaviour whilst isolate AH18 was slightly different. This observation was similar to Kantachote et al. (2008) works in which using API 20E kit to validate the utilisation of organic compounds. Moreover, yeast extract has become favourable organic compound by all the potential SOB due to various of amino acid and peptides contents in yeast extract and the water-soluble characteristic of vitamins and carbohydrates molecule which are enough to sup- port the bacterial growth of the isolates. However, by adding organic compound (yeast extract) into the corresponding TSM liquid medium, the bacterial growth was significantly enhanced. In addition, the greatest sulphate ion formation also was observed in medium containing both thiosulphate and yeast extract compared with medium containing the only thiosulphate. Thus, it appears that the isolates preferred mixotrophic growth because the bacteria grow better with the presence of both reduced inorganic sulphur compound and an organic compound. Similar works have also reported that mixotrophy growth with yeast extract was found to be a great condition which promotes the growth of bacteria and the oxidation process of sulphur compounds resulting in higher sulphate ion production (Vardanyan \& Vardanyan, 2014; Kantachote et al., 2008; Chen et al., 2004). Hence, the metabolic flexibility might ensure better survival and the growth of SOB in various environments (Graff \& Stubner, 2003), especially in the absence of reduced inorganic sulphur compounds sources.

It is important to determine the adaptability and feasibility of the SOB in the various environmental conditions as described above to ensure their effectiveness in biological deodorisation performance. Therefore, it was ascertained from this present investigation that the potential SOB isolates have possessed a good application potential for the biological deodorisation of $\mathrm{H} 2 \mathrm{~S}$ in chicken manure due to their ability to perform the oxidisation of sulphur compound at various parameters tested.

\section{CONCLUSION}

It was concluded that three potential SOB isolates were successfully isolated from hot spring in Malaysia which have remarkable potentials for application in the biological deodorisation of $\mathrm{H}_{2} \mathrm{~S}$ in chicken manure. The results of the present study revealed that the potential isolates of $\mathrm{AH} 18, \mathrm{AH} 25$, and $\mathrm{AH} 28$ capable of oxidising of thiosulphate up to a concentration of $100 \mathrm{mM}$. The optimum $\mathrm{pH}$ was 8.0 and optimum temperatures of isolate AH18, AH25, AH28 were at $45^{\circ} \mathrm{C}, 30-45^{\circ} \mathrm{C}$, and $30{ }^{\circ} \mathrm{C}$, respectively, which makes them appropriate candidates for the biological deodorisation. Moreover, all the potential isolates were classified as facultative chemolithotroph and this metabolic versatility could be an advantage to survive in various environmental conditions. All the data gathered in this study could be useful information in developing a feasible biological deodorisation strategy.

\section{ACKNOWLEDGEMENT}

The authors extend their appreciation to Universiti Putra Malaysia (UPM) for financing this work through Putra Graduate Initiative (IPS).

\section{REFERENCES}

Baioumy, H., M. Nawawi, K. Wagner, \& M. H. Arifin. 2015. Geochemistry and geothermometry of non-volcanic hot springs in West Malaysia. J. Volcanol. Geotherm. Res. 290: 
12-22. https://doi.org/10.1016/j.jvolgeores.2014.11.014

Bezsudnova, E. Yu., D. Yu. Sorokin, T. V. Tikhonova, \& V. O. Popov. 2007. Thiocyanate hydrolase, the primary enzyme initiating thiocyanate degradation in the novel obligately chemolithoautotrophic halophilic sulphur oxidizing bacterium Thiohalophilus thiocyanoxidans. Biochim. Biophys. Acta. 1774: 1563-1570. https://doi.org/10.1016/j. bbapap.2007.09.003

Cha, J. M., W. S. Cha, \& J. H. Lee. 1999. Removal of organosulphur odour compounds by Thiobacillus novellus SRM, sulphur-oxidizing bacteria. Process. Biochem. 34: 659-665. https://doi.org/10.1016/S0032-9592(98)00139-3

Chen, X.G., A. L. Geng, R. Yan, W. D. Gould, Y. L. Ng, \& D. T. Liang. 2004. Isolation and characterisation of sulphuroxidising Thiomonas sp. and its potential application in biological deodorisation. Lett. Appl. Microbiol. 39: 495-503. https://doi.org/10.1111/j.1472-765X.2004.01615.x

Chung, Y. C., C. Huang, \& C. P. Tseng. 1996. Biodegradation of hydrogen sulphide by a laboratory-scale immobilised Pseudomonas putida CH11 biofilter. Biotechnol. Prog. 12: 773-778. https://doi.org/10.1021/bp960058a

Chung, Y. C., K. L. Ho, \& C. P. Tseng. 2007. Two-stage biofilter for effective $\mathrm{NH} 3$ removal from waste gases containing high concentrations of H2S. J. Air. Waste. Manag. Assoc. 57: 337-347. https://doi.org/10.1080/10473289.2007.104653 32

De Gusseme, B., P. De Schryver, M. De Cooman, K. Verbeken, P. Boeckx, W. Verstraete, \& N. Boon. 2009. Nitrate-reducing, sulphide-oxidizing bacteria as microbial oxidants for rapid biological sulphide removal. FEMS. Microb. Ecol. 67: 151161. https://doi.org/10.1111/j.1574-6941.2008.00598.x

Dehghanzadeh, R., H. Aslani, A. Torkian, \& M. Asadi. 2011. Interaction of acrylonitrile vapours on a bench scale biofilter treating styrene-polluted waste gas streams. Iranian. J. Environ. Health. Sci. Eng. 8: 159-168.

Druschel, G. K., M. A. A. Schoonen, D. K. Nordstrom, J. W. Ball, Y. Xu, \& C. A. Cohn. 2003. Sulphur geochemistry of hydrothermal waters in Yellowstone National Park, Wyoming, USA. III. An anion-exchange resin technique for sampling and preservation of sulfoxyanions in natural waters. Geochem. Trans. 4: 12-19. https://doi. org/10.1186/1467-4866-4-12

Ehrlich, H.L. \& D. K. Newman. 2009. Geomicrobiology of Sulfur. Geomicrobiology. 5th ed. CRC Press, Boca Raton, p. 439-489.

Graff, A. \& S. Stubner. 2003. Isolation and molecular characterisation of thiosulphate-oxidising bacteria from an Italian rice field soil. Syst. Appl. Microbiol. 26: 445-452. https:// doi.org/10.1078/072320203322497482

Gutarowska, B., K. Matusiak, S. Borowski, A. Rajkowska, \& B. Brycki. 2014. Removal of odorous compounds from poultry manure by microorganisms on perlite-bentonite carrier. J. Environ. Manag. 141: 70-76. https://doi.org/10.1016/j. jenvman.2014.03.017

Hassan, S. H. A., W. Steven, V. Ginkel, S. M. Kim, S. H. Yoon, S. H. Joo, B. S. Shin, B. H. Jeon, W. Bae, \& S. E. Oh. 2010. Isolation and characterisation of Acidithiobacillus caldus from a sulphur-oxidising bacterial biosensor and its role in detection of toxic chemicals. J. Microbiol. Methods. 82: 151-155. https://doi.org/10.1016/j.mimet.2010.05.008

Ho, K. L., Y. C. Chung, Y. H. Lin, \& C. P. Tseng. 2008. Microbial population analysis and field application of biofilter for the removal of volatile-sulphur compounds from swine wastewater treatment system. J. Hazard. Mater. 152: 580588. https://doi.org/10.1016/j.jhazmat.2007.07.021

Hucker, G. J. 1921. A new modification and application of the gram stain. J. Bacteriol. 6: 395-397.

Kantachote, D., W. Charernjiratrakul, N. Noparatnaraporn, \& K. Oda. 2008. Selection of sulphur oxidising bacterium for sulphide removal in sulphate rich wastewater to enhance biogas production. Electron. J. Biotechnol. 11: 1-12. https:// doi.org/10.2225/vol11-issue2-fulltext-13

Kim, K. Y., H. J. Ko, H. T. Kim, Y. S. Kim, Y. M. Roh, C. M. Lee, H. S. Kim, \& C. N. Kim. 2007. Sulphuric odorous compounds emitted from pig-feeding operations. Atmos. Environ. 41: 4811-4818. https://doi.org/10.1016/j. atmosenv.2007.02.012

Kolmert, Å., P. Wikström, \& K. B. Hallberg. 2000. A fast and simple turbidimetric method for the determination of sulphate in sulphate-reducing bacterial cultures. J. Microbiol. Methods. 41: 179-184. https://doi.org/10.1016/ S0167-7012(00)00154-8

Kuenen, J. G., L. A. Robertson, \& O. H. Tuovinen. 1992. The genera Thiobacillus, Thiomicrospira and Thiosphaera. In: A. Balows, H. G. Truper, M. Dworki, W. Harder, \& K. H. Schleifer (Eds). The prokaryotes. New York. SpringerVerlag. p. 2636-2657.

Lee, E. Y., K. S. Cho, \& H. W. Ryu. 2000. Characterisation of sulphur oxidation by an autotrophic sulphur oxidiser, Thiobacillus sp. ASWW-2. Biotechnol. Bioprocess. Eng. 5: 48-52. https://doi.org/10.1007/BF02932353

Lin, W.C., Y. P. Chen, \& C. P. Tseng. 2013. Pilot-scale chemicalbiological system for efficient $\mathrm{H} 2 \mathrm{~S}$ removal from biogas. Bioresour. Technol. 135: 283-291. https://doi.org/10.1016/j. biortech.2012.10.040

Makzum, S., M. A. Amoozegar, S. M. M. Dastgheib, H. Babavalian, H. Tebyanian, \& F. Shakeri. 2016. Study on Haloalkaliphilic sulphur oxidising bacterium for thiosulphate removal in treatment of sulfidic spent caustic. ILNS. 57: 49-57. https://doi.org/10.18052/www.scipress.com/ ILNS.57.49

Olguin-Lora, P., S. Le Borgne, G. Castorena-Cortes, T. Roldan-Carrillo, I. Zapata-Penasco, J. Reyes-Avila, \& S. Alcantara-Perez. 2011. Evaluation of haloalkaliphilic sulphur-oxidizing microorganisms with potential application in the effluent treatment of the petroleum industry. Biodegradation. 22: 83-93. https://doi.org/10.1007/ s10532-010-9378-4

Oprime, M. E. A. G., O. J. Garcia, \& A. A. Cardoso. 2001. Oxidation of $\mathrm{H} 2 \mathrm{~S}$ in acid solution by Thiobacillus ferrooxidans and Thiobacillus thiooxidans. Process. Biochem. 37: 111114. https://doi.org/10.1016/S0032-9592(01)00179-0

Park, S. J., V. H. Pham, M. Y. Jung, S. J. Kim, J. G. Kim, D. H. Roh, \& S. K. Rhee. 2011. Thioalbus denitrifications gen. nov., sp. nov., a chemolithoautotrophic sulphur-oxidising gammaproteobacterium, isolated from marine sediment. Int. J. Syst. Evol. Microbiol. 61: 2045-2051. https://doi. org/10.1099/ijs.0.024844-0

Pokorna, D., \& J. Zabranska. 2015. Sulphur-oxidising bacteria in environmental technology. Biotechnol. Adv. 33: 12461259. https://doi.org/10.1016/j.biotechadv.2015.02.007

Shi, J., H. Lin, X. Yuan, \& Y. Zhao. 2011. Isolation and characterisation of a novel sulphur oxidising chemolithoautotroph Halothiobacillus from Pb-polluted paddy soil. Afr. J. Biotechnol. 10: 4121-4126.

Skirnisdottir, S., G. O. Hreggvidson, O. Holst, \& J. K Kristjansson. 2001a. Isolation and characterisation of a mixotrophic sulphur-oxidising Thermus scotoductus. Extremophiles. 5: 45-51. https://doi.org/10.1007/ s007920000172

Skirnisdottir, S., G. O. Hreggvidson, O. Holst, \& J. K. Kristjansson. 2001b. A new ecological adaptation to high sulphide by Hydrogenobacter sp. growing on sulphur compounds but not on hydrogen. Microbiol. Res. 156: 41-47. https://doi.org/10.1078/0944-5013-00068

Skirnisdottir, S., G. O. Hreggvidsson, S. Hjorleifsdottir, V. T. Marteinsson, S. K, Petursdottir, \& O. Holst. 2000. Influence of sulphide and temperature on species composition and 
community structure of hot spring microbial mats. Appl. Environ. Microbiol. 66: 2835-2841. https://doi.org/10.1128/ AEM.66.7.2835-2841.2000

Sorokin, D.Y., V. M. Gorlenko, T. P. Tourova, A. I. Tsapin, K. H. Nealson, \& J. G. Kuenen. 2002. Thioalkalimicrobium cyclicum sp. nov. and Thioalkalivibrio jannaschii sp. nov., novel species of haloalkaliphilic, obligately chemolithoautotrophic sulphur-oxidizing bacteria from hypersaline alkaline Mono Lake (California). Int. J. Syst. Evol. Microbiol. 52: 913-920.

Sorokin, D. Y., B. Abbas, E. V. Zessen, \& G. Muyzer. 2014. Isolation and characterization of an obligately chemolithoautotrophic Halothiobacillus strain capable of growth on thiocyanate as an energy source. FEMS. Microbiol. Lett. 354: 69-74. https://doi.org/10.1111/1574-6968.12432

Spring, S., P. Kämpfer, \& K. H. Schleifer. 2001. Limnobacter thiooxidans gen. nov., sp. nov., a novel thiosulphate-oxidising bacterium isolated from freshwater lake sediment. Int. J. Syst. Evol. Microbiol. 51: 1463-1470. https://doi. org/10.1099/00207713-51-4-1463

Takano, B., M. Koshida, Y. Fujiwara, K. Sugimori, \& S. Takayanagi. 1997. Influence of sulphur-oxidizing bacteria on the budget of sulphate in Yugama crater lake, KusatsuShirane volcano, Japan. Biogeochemistry. 38: 227-253. https://doi.org/10.1023/A:1005805100834

Ullah, I., G. Jilani, M. I. Haq, \& A. Khan. 2013. Enhancing bioavailable phosphorous in soil through sulphur oxidation by Thiobacilli. Br. Microbiol. Res. J. 3(3): 378-392. https:// doi.org/10.9734/BMRJ/2013/4063

Vardanyan, N. S., \& A. K. Vardanyan. 2014. New sulphur oxidising bacteria isolated from bioleaching pulp of zinc and copper concentrates. Univers. J. Microbiol. Res. 2: 27-31.
Vikromvarasiri, N., S. Boonyawanich, \& N. Pisutpaisal. 2015. Optimizing sulphur oxidising performance of Paracoccus pantotrophus isolated from leather industry wastewater. Energy. Procedia. 79: 629-633. https://doi.org/10.1016/j. egypro.2015.11.544

Vidyalakshmi, R. \& R. Sridar. 2007. Isolation and characterization of sulphur oxidizing bacteria. J. Cult. Collect. 5: 73-77.

Vlasceanu, L., P. Radu, \& B. R. Kinkle. 1997. Characterisation of Thiobacillus thioparus LV43 and its distribution in a chemoautotrophically based groundwater ecosystem. Appl. Environ. Microbiol. 63: 3123-3127.

Watsuntorn, W., C. Ruangchainikom, E. R. Rene, P.N.L. Lens, \& W. Chulalaksananukul. 2017. Hydrogen sulphide oxidation under anoxic conditions by a nitrate- reducing, sulphide-oxidsing bacterium isolated from the Mae Um Long Luang hot spring, Thailand. Int. Biodeterior. Biodegradation. 124: 196-205. https://doi.org/10.1016/j. ibiod.2017.06.013

Xu, X. J., C. Chen, H. Guo, A. Wang, N. Ren, \& D. J. Lee. 2016. Characterization of a newly isolated strain Pseudomonas sp. C27 for sulphide oxidation: Reaction kinetics and stoichiometry. Sci. Rep. 6:21032. http://doi.org/10.1038/srep21032 [22 November 2017]. https://doi.org/10.1038/srep21032

Yang, Z. H., K. Stoven, S. Haneklaus, B. R. Singh, \& E. Schnug. 2010. Elemental sulphur oxidation by Thiobacillus spp. and aerobic heterotrophic sulphur-oxidising bacteria. Pedosphere. 20: 71-79. https://doi.org/10.1016/ S1002-0160(09)60284-8 